\title{
HPLC phenolic profile and induction of apoptosis by Linum usitatissimum extract in LNCaP cells by caspase 3 and Bax pathways
}

Xin Zhou ${ }^{1 \dagger}$, Ningou Huang ${ }^{2 \dagger}$, Wenxin Chen ${ }^{3}$, Tang Xiaoling ${ }^{4^{*}}$ (1) Behnam Mahdavi ${ }^{5}$, Amir Raoofi ${ }^{6}$, Davood Mahdian ${ }^{7}$ and Hadi Atabati ${ }^{6}$

\begin{abstract}
Linum usitatissimum is a candidate as a remedy to treat prostate problems in some folklore medicines. In this study, we have reported the phenolic and flavonoid constituents, antioxidant activity, and potential of the plant extract against prostate cancer cells. The phenolic and flavonoid compound profile of the extract were established using HPLC analysis. While the total phenolic and flavonoid content (TPC and TFC) were analyzed using classic methods. The antioxidant activity of the extract was also evaluated. MTT assay and flow cytometry technique was used to evaluate antiproliferation activity and induction apoptosis of the plant extract on prostate cancer cells of LNCaP. We also evaluated the gene expression of Bax and caspase-3 using the real-time qPCR assay. HPLC result revealed that L. usitatissimum extract (LUE) was rich in phenolic acids such as gallic, ferulic, and vanillic acid with the amount of 3.56, 2.12, $1.24 \mu \mathrm{g} / \mathrm{g}$ extract respectively. $383.4 \mathrm{mg} \mathrm{GAE} / \mathrm{g}$ and $47.1 \mathrm{mgRuE} / \mathrm{g}$ were calculated for total phenolic and flavonoid content. LUE exhibited radical scavenging activity with $I C_{50}=19.3 \pm 1.1 \mu \mathrm{g} / \mathrm{mL}$. LUE chelated ferrous ions with $I C_{50}=121.1 \pm 1.3 \mu \mathrm{g} / \mathrm{mL}$. LUE showed anti-proliferative activity on LNCaP cells with the $I C_{50}$ values of $8.3,6.3$, and $5.4 \mu \mathrm{g} / \mathrm{mL}$ after 24,48 , and $72 \mathrm{~h}$ treatment. LUE also increased cell mortality by inducing apoptosis (15.3-29.8\%). The real-time qPCR results exhibited an increase in gene expression of Bax and caspase-3. Our in vitro study demonstrates that L. usitatissimum can be considered as an effective agent to inhibit the growth and invasion the human prostate cancer cells.
\end{abstract}

Keywords: Linum usitatissimum, Phenolic profile, Prostate cancer, Induction apoptosis, Bax, Caspase-3

\section{Introduction}

Prostate cancer $(\mathrm{PCa})$ is the most common form of cancer among males. But if detected in the early stages, because of the slow progression of the disease, the survival rates are high (Yoo et al. 2019; Chen et al. 2019). The problem is typically observed in men with middle age or older (Yoon et al. 2016). The treatment decisions are chosen based on tumor aggressiveness (Abou-Hashem et al. 2019). Surgery, chemotherapy, or hormone therapy are

\footnotetext{
*Correspondence: tx1123666@sina.com

${ }^{\dagger}$ Xin Zhou and Ningou Huang contributed equally to this work

4 Jiangxi Research Institute of Traditional Chinese Medicine,

Nanchang 330046, Jiangxi, China

Full list of author information is available at the end of the article
}

common ways to treat PCa (Dasari et al. 2018b; Mirza et al. 2018), while natural plant products are candidates to treat $\mathrm{PCa}$ in some traditional medicine systems around the world. Black pepper, ginger, chili, and turmeric, due to their secondary metabolites, have been known as the plants with anticancer properties (Dasari et al. 2018b). Hence, development in a novel natural therapeutic agent field is vital to improve the overall survival of people with $\mathrm{PCa}$. On the other hand, dietary constituents are also critical probable risk factors in treating prostate cancer. In recent years, nutritional agents such as lycopene, vitamin $C$, and vitamin $K$, which possess anticancer activity, play an important role in various researches related to cancer problems (Dasari et al. 2018a).
Springer Open

(c) The Author(s) 2020. This article is licensed under a Creative Commons Attribution 4.0 International License, which permits use, sharing, adaptation, distribution and reproduction in any medium or format, as long as you give appropriate credit to the original author(s) and the source, provide a link to the Creative Commons licence, and indicate if changes were made. The images or other third party material in this article are included in the article's Creative Commons licence, unless indicated otherwise in a credit line to the material. If material is not included in the article's Creative Commons licence and your intended use is not permitted by statutory regulation or exceeds the permitted use, you will need to obtain permission directly from the copyright holder. To view a copy of this licence, visit http://creativeco mmons.org/licenses/by/4.0/. 
Linum usitatissimum is known with the common name of flax or linseed. The plant is a member of the Linaceae family (Safarpoor et al. 2018). Flax is one of the most ancient crops with some specific in cloths and paper industries (Wei et al. 2018). Flaxseed is a valuable source of dietary fibers (Nwachukwu and Aluko 2018). The plant seeds are a source of carbohydrates, phenolic, flavonoids compounds, and lignans. Hemicellulose and cellulose are the main carbohydrates; ferulic, chlorogenic, gallic, and 4-hydroxybenzoic acids are the main phenolic compounds; secoisolariciresinol diglucoside is the main lignan, and herbacetin diglucoside is the main flavonoid compound in the plant (Herchi et al. 2016; Lazić et al. 2018; Garros et al. 2018; Fadzir et al. 2018). L. usitatissimum also contains fatty acids such as $\alpha$-linolenic, linoleic, and oleic acid as well as mucilage vitamin B1, and vitamin A (Duygu and Yilmaz 2018). The plant is a good source of minerals such as magnesium, phosphorus, manganese, selenium, and zinc (Calado et al. 2018). Many reports are indicating that flaxseed possesses various bioactivities such as anticancer, anti-obesity, anti-diabetic activity, antiviral, antibacterial, anti-inflammatory antioxidant activity, and cardio-protective agent (Hu et al. 2019; Zhu and Li 2019a, b). Some researchers have proposed that flaxseed is a potential agent to reduce the proliferation of breast cancer (Calado et al. 2018), colon cancer (DeLuca et al. 2018), and skin cancer cells (Sharma et al. 2014).

In the texts related to traditional medicines, $L$. usitatissimum has been proposed to cure prostate problems (Azadbakht et al. 2019). Hence, in this study, we focus on evaluating the antiproliferation and induced apoptosis of the hydroalcoholic extract of L. usitatissimum on the human prostate cancer cells of LNCap. We have also studied the effect mechanism of the extract through the gene expression of Bax and caspase 3.

\section{Materials and methods}

\section{Preparation of plants extracts}

Linum usitatissimum seeds were purchased from a medicinal plant store (Sabzevar, Iran). The seed was ground and macerated in ethanol:water (70:30) for $72 \mathrm{~h}$. After filtration, the solvent was evaporated under reduced pressure using a Buchi evaporator $\left(50{ }^{\circ} \mathrm{C}\right)$. Finally, L. usitatissimum extract (Urhan et al. 2020) was dried in an oven at $50^{\circ} \mathrm{C}$.

\section{HPLC analysis and identification of the main compounds} Extract at a concentration of $10 \mathrm{mg} / \mathrm{mL}$ in methanol was analyzed by HPLC (Waters 2695 (USA) and a PDA detector Waters 996 (USA) as described previously with some modification in the gradient system and flow rate (Gabr et al. 2018). The chromatographic assay was performed on a $15 \mathrm{~cm} \times 4.6 \mathrm{~mm}$ with pre-column, Eurospher 100 $5 \mathrm{C}_{18}$ analytical column provided by Waters (Sunfire) reversed-phase matrix $(3.5 \mu \mathrm{m})$ (Waters). Elution was carried out in a gradient program with $0.5 \%(\mathrm{v} / \mathrm{v})$ aqueous phosphoric acid (eluent $\mathrm{A}$ ) and of $40 \%(\mathrm{v} / \mathrm{v})$ aqueous

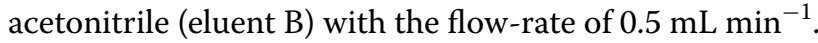
Peaks were monitored at wavelengths of $254,278,300$, and $370 \mathrm{~nm}$. The injection volume was $20 \mu \mathrm{L}$, and the temperature was maintained at $35{ }^{\circ} \mathrm{C}$. The constituents were recognized by comparison of the retention time and UV-Vis. spectral reference data with those of the standard controls. The amounts of the various compounds were extrapolated from calibration standard curves. All standards were purchased from Sigma- Aldrich.

\section{Antioxidant activity assays}

Determination of total phenolic content (TPC), total flavonoid content (TFC), radical scavenging activity (RSA), ferrous ion chelating (FIC) were carried out according to previous studies (Mahdavi et al. 2013; Hosseinpoor Mohsen Abadi et al. 2016). The chemicals for antioxidant assays were prepared from different companies as following:1,1-diphenyl-2-picrylhydrazyl (DPPH), $\alpha$-tocopherol, 3-(2-pyridyl)-5,6-bis(4-phenylsulfonic acid)-1,2,4-triazine (ferrozine), butylated hydroxytoluene (BHT) were purchased from Sigma; ascorbic acid (Pallag et al. 2016), and EDTA from Merck; $\mathrm{Na}_{2} \mathrm{CO}_{3}, \mathrm{AlCl}_{3}$, $\mathrm{FeSO}_{4} \cdot 7 \mathrm{H} 2 \mathrm{O}$, Folin-Ciocalteu's reagent (FCR) from Fluka; gallic acid (GA) from Acros; and all solvents of analytical grade were obtained from Merck.

\section{Determination of total phenolic content (TPC)}

A $0.5 \mathrm{~mL}$ of FCR (10\% in distilled water) was added to $0.5 \mathrm{~mL}$ of the extract $(100 \mu \mathrm{g} / \mathrm{mL}$ in methanol $)$ and $1.5 \mathrm{~mL}$ of distilled water. After $5 \mathrm{~min}$, two $\mathrm{mL}$ of $\mathrm{Na}_{2} \mathrm{CO}_{3}$ (5\%) was added and shaken again. The mixture was kept in the dark for $2 \mathrm{~h}$ at room temperature. The absorbance was read at $760 \mathrm{~nm}$ using a Photonix Ar 2015 UV-Vis. instrument. The analyses were run in triplicates. TPC was measured as gallic acid equivalent (GAE), that is, $\mathrm{mg}$ of gallic acid equivalent per gram of extract (mg GAE/g extract).

\section{Determination of total flavonoid content (TFC)}

A mixture of the plant extract $(1 \mathrm{~mL}, 100 \mu \mathrm{g} / \mathrm{mL})$ and a methanolic solution of $\mathrm{AlCl}_{3}(1 \mathrm{~mL}, 2 \%)$ was kept at room temperature for $30 \mathrm{~min}$. Then, the mixture absorbance was read at $415 \mathrm{~nm}$. The analyses were run in triplicates. TFC amount was obtained using a standard curve of rutin $(10-160 \mu \mathrm{g} / \mathrm{mL})$. TFC was expressed in $\mathrm{mg}$ of rutin equivalent per gram of dried extract (mg RuE/g extract). 


\section{Determination of radical scavenging activity (RSA)}

A $1.5 \mathrm{ml}$ of methanolic solution of LUE $(5-30 \mu \mathrm{g} / \mathrm{mL})$ was added to $1 \mathrm{~mL}$ of DPPH $(0.1 \mathrm{mM})$. The mixture was shaken and kept in the dark for $90 \mathrm{~min}$ at room temperature; the absorbance was read at $517 \mathrm{~nm}$. Positive controls of butylated hydroxytoluene (BHT) and $\alpha$-tocopherol (Toc) were used. All analyses were run in triplicates. The RSA was calculated using the following equation:

$$
\mathrm{RSA} \%=\left[\left(\mathrm{A}_{\mathrm{c}}-\mathrm{A}_{\mathrm{s}}\right) / \mathrm{A}_{\mathrm{c}}\right] \times 100
$$

where $A_{c}$ is the absorbance of the control (DPPH solution without extract), and $A_{s}$ is the absorbance of the extract (extract with DPPH solution).

\section{Ferrous ion chelating ability assay}

First. A mixture of $\mathrm{FeSO}_{4}(50 \mu \mathrm{L}, 2 \mathrm{mM})$, the plant extract solution in methanol $(1 \mathrm{~mL}, 40-200 \mu \mathrm{g} / \mathrm{mL})$, and distilled water $(2 \mathrm{~mL})$ was prepared. Then, ferrozine $(100 \mu \mathrm{L}, 5 \mathrm{mM})$ was added. The mixture was shaken and incubated at room temperature for $10 \mathrm{~min}$. The absorbance was read at $562 \mathrm{~nm}$. All evaluations were carried out in triplicates. EDTA (disodium salt) and ascorbic acid (AscA) were used as the positive controls. FIC for the plant extract was determined using the following equation:

$$
\text { \% Inhibition }=\left[\left(\mathrm{A}_{\mathrm{c}}-\mathrm{A}_{\mathrm{s}}\right) / \mathrm{A}_{\mathrm{c}}\right] \times 100
$$

where $A_{c}$ is the absorbance of the control (contains $\mathrm{FeSO}_{4}$, ferrozine, and water), and $\mathrm{A}_{\mathrm{s}}$ is the absorbance of the sample.

\section{MTT assay}

The prostate cancer cell line (LNCaP) was purchased from Pastor Institute (Iran). Dulbecco's modified Eagle's medium (GIBCO, England) supplemented with 10\% fetal bovine serum (GIBCO, England) and 5\% penicillin (Sigma Aldrich, USA) was used. The cytotoxicity of LUE on LNCaP cells was studied using MTT assay according to a previous report with some modifications $(\mathrm{Ni}$ et al. 2019). Briefly, the cells were uniformly distributed $\left(5 \times 10^{3}\right.$ cells in each well $)$ in a 96-wells plate and incubated at $37{ }^{\circ} \mathrm{C}$ with $5 \% \mathrm{CO}_{2}$, overnight. Then LUE at different concentrations $(2-10 \mu \mathrm{g} / \mathrm{mL})$ was added to the wells and incubated for 24, 48, and $72 \mathrm{~h}$. Next, MTT (20 $\mu \mathrm{l}, 5 \mathrm{mg} / \mathrm{mL}$ in PBS) was added to the wells and incubated at $37^{\circ} \mathrm{C}$ for $4 \mathrm{~h}$. Finally, the formazan crystals were dissolved in dimethyl sulfoxide (DMSO) $(100 \mu \mathrm{L})$ and the optical density was read at the wavelength of $570 \mathrm{~nm}$ and 630 (control wavelength) by a plate reader (Thermo Lab systems, Franklin, MA USA). $\mathrm{IC}_{50}$ (concentration of the extract that attained a $50 \%$ of mortality) of LUE was determined through Prism software. All treatments run in triplicate. In the MTT assay of the present study, DMSO was used as negative control and Docetaxel $(0.1 \mu \mathrm{M})$ was the positive control.

\section{Cell proliferation}

MTT assay was used to examine the cell proliferation. The cells in the density of $2 \times 10^{3}$ cells $/ \mathrm{mL}$ were plated in a 96 wells cell culture plate for $12 \mathrm{~h}$. Next, various treatments were incubated for $48 \mathrm{~h}$ at $37{ }^{\circ} \mathrm{C}$ and $5 \% \mathrm{CO}_{2}$. Then, $5 \mathrm{mg} / \mathrm{mL}$ of MTT powder (Sigma) was added to each well for $3 \mathrm{~h}$. The supernatant of each well was removed. The formazan crystals were dissolved in DMSO $(100 \mu \mathrm{L})$ at room temperature. Finally, we used $200 \mu \mathrm{L}$ of DMSO for each well. The absorption of various treatments were read in 570 and $630 \mathrm{~nm}$ references using an enzyme-linked immunosorbent assay (ELISA) Reader (Ni et al. 2019).

\section{Secretion of TNFa}

The Rat inflammatory cytokine assay kit, Rat Kit V-Plex was used to measure the TNF $\alpha$ concentration.

\section{Flowcytometric analysis}

A quantitative assessment of apoptosis was carried out using propidium iodide (PI) staining of small DNA fragments followed by flow cytometry. The assay was carried out according to a previous report (Kilinc et al. 2020). Briefly, LNCaP cells were cultured $\left(1.5 \times 10^{5}\right.$ cells $)$ with $10 \%$ FBS involved media and incubated for $24 \mathrm{~h}$ at $37^{\circ} \mathrm{C}$ and $5 \% \mathrm{CO}_{2}$. Next, the media was changed with serumfree media for $6 \mathrm{~h}$ and treated with LUE with different concentrations and times: $6,8.3$, and $10 \mu \mathrm{g} / \mathrm{mL}$ for $24 \mathrm{~h}$; 4, 6.3, and $8 \mu \mathrm{g} / \mathrm{mL}$ for $48 \mathrm{~h}$; and 4, 5.4, and 6 for $72 \mathrm{~h}$. After incubation, floating and adherent cells were intake and incubated overnight with $750 \mu \mathrm{L}$ of a hypotonic buffer consist of $50 \mathrm{mg} / \mathrm{ml} \mathrm{PI}$ in sodium citrate $(0.1 \%)$ with Triton X-100 $(0.1 \%)$ at $4{ }^{\circ} \mathrm{C}$ in the dark. Next, flow cytometry was carried out using a flow cytometer (Becton Dickinson). A total of $1 \times 10^{4}$ events were achieved with FACS and data were analyzed through flow Jo- V10 software.

\section{Real-Time Quantitative RT-PCR}

Notably, qRT-PCR has been selected to evaluate the level of Bax and caspase 3 expression. 500,000 of LNCaP cells were seeded in 6-well plates and incubated overnight. Then cells were exposed to LUE for 24,48 and $72 \mathrm{~h}$ with $\mathrm{IC}_{50}$ doses. Furthermore, the total RNA has been derived from cell samples using the company guidelines for Trizol reagent. Then, cDNA has been synthesized according to the total RNA via a Prime-Script RT reagent kit with gDNA Eraser (Takara: Dalian). For reverse transcription-polymerase chain reaction (RT-PCR), the PCR 
reaction involved 35 cycles of denaturation for thirty seconds at $94{ }^{\circ} \mathrm{C}$, an extension for thirty seconds at $72{ }^{\circ} \mathrm{C}$, and Annealing for thirty seconds at $54{ }^{\circ} \mathrm{C}$. Besides, PCR products for Bax and casp3 respectively have been 108 and $70 \mathrm{bp}$. Table 1 presents the primers. To obtain the real-time quantitative RT-PCR, we used the Fast-Start Universal SYBR Green Master (Roche: USA) over a Master cycle repeal plex 4 system to carry out the processes. Each reaction runs for three times. Finally, the comparative $2^{-} \Delta \Delta \mathrm{Ct}$ method has been used to determine mRNAs relative expression and then data normalized versus GAPDH.

\section{Results}

\section{HPLC analysis}

Figure 1 presents the HPLC chromatogram of LUE. The obtained results for the HPLC analysis are revealed in Table 2. Among the selected standards, including eight phenolic acids (gallic, vanillic, chlorogenic, caffeic, $p$-coumaric, sinapic, ferulic, and trans-o-hydroxy cinnamic acid) and two flavonoids (quercetin and rutin), LUE was rich in gallic, ferulic, and vanillic acid with the amount of 3.56, 2.12, $1.24 \mu \mathrm{mol} / \mathrm{g}$ extract respectively. According to our literature review, the presence of quercetin $(0.16 \mu \mathrm{mol} / \mathrm{g}$ extract $)$ and rutin $(0.24 \mu \mathrm{mol} / \mathrm{g}$ extract $)$ is reported for the first time.

\section{Total phenolic content (TPC) and total flavonoid content (TFC)}

TPC and TFC results of LUE are exhibited in Table 3. According to the results, $383.4 \mathrm{mg}$ GAE/g was calculated for TPC of the extract; while, $47.1 \mathrm{mgRuE} / \mathrm{g}$ was measured for TFC of L. usitatissimum extract.

\section{Radical scavenging activity (RSA) and ferrous ion Chelating (FIC)}

The results are shown in Table 3. The extract with $\mathrm{IC}_{50}$ of $19.27 \pm 1.1 \mu \mathrm{g} / \mathrm{mL}$ showed radical scavenging activity stronger than the positive control ( $\alpha$-tocopherol), but weaker than BHT. For FIC assay, LUE with $\mathrm{IC}_{50}$ of

Table 1 Primer sequences of Bax, Caspase-3, and GAPDH

\begin{tabular}{|c|c|c|c|c|}
\hline Gene & Sequence & Primer sequence & Annealing & $\begin{array}{l}\text { Product } \\
\text { size (bp) }\end{array}$ \\
\hline $\operatorname{Bax}$ & $\begin{array}{l}F \\
R\end{array}$ & $\begin{array}{l}\text { TTCCGAGTGGCAGCTGAGATGTTT } \\
\text { TGCTGGCAAAGTAGAAGAGGGCAA }\end{array}$ & $54{ }^{\circ} \mathrm{C} \times 30 \mathrm{~s}$ & 108 \\
\hline Caspase-3 & $\begin{array}{l}F \\
R\end{array}$ & $\begin{array}{l}\text { ACTGGACTGTGGCATTGAGA } \\
\text { GCACAAAGCGACTGGATGAA }\end{array}$ & $54{ }^{\circ} \mathrm{C} \times 30 \mathrm{~s}$ & 70 \\
\hline GAPDH & $\begin{array}{l}F \\
R\end{array}$ & $\begin{array}{l}\text { ATCTGACATGCTGCCTGGAG } \\
\text { AAGGTTGGAAGATGGGAGTTGC }\end{array}$ & $60^{\circ} \mathrm{C} \times 25 \mathrm{~s}$ & 88 \\
\hline
\end{tabular}

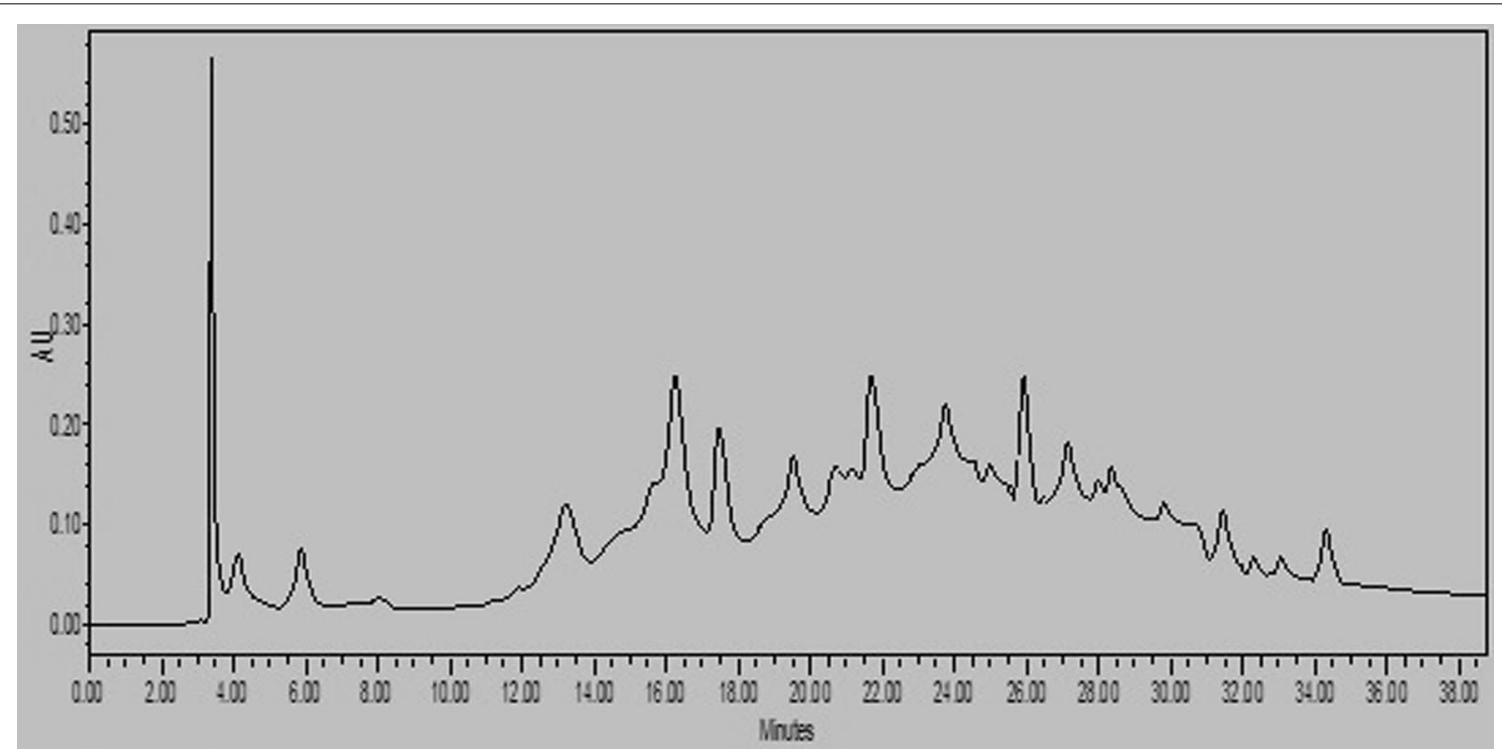

Fig. 1 HPLC chromatogram of Linum usitatissimum Extract. Identification and quantification of compounds was done by comparing retention time and spectra of the peaks in the extract against that of the standard compounds 
Table 2 HPLC results of selected phenolics and flavonoids of Linum usitatissimum seeds extract

\begin{tabular}{|c|c|c|c|c|c|}
\hline Compounds & Wavelength $\mathrm{nm}$ & $\mathrm{RT}$ (min.) & $\mu \mathrm{mol} / \mathrm{g}$ extract & $\mu \mathrm{g} / \mathrm{g}$ extract & Area \\
\hline \multicolumn{6}{|l|}{ Phenolic acids } \\
\hline Gallic acid & 278 & 5.86 & 3.56 & 605.62 & $1,803,295$ \\
\hline Vanillic acid & 254 & 13.67 & 1.24 & 208.5 & 478,244 \\
\hline Chlorogenic acid & 300 & 16.27 & 1.23 & 435.8 & $1,101,354$ \\
\hline Caffeic acid & 300 & 17.62 & 0.15 & 27.04 & 68,663 \\
\hline p-Coumaric acid & 300 & 22.24 & 0.43 & 82.56 & 208,254 \\
\hline Sinapic acid & 300 & 23.96 & 0.98 & 319.77 & $1,321,751$ \\
\hline Ferulic acid & 300 & 25.93 & 2.12 & 411.66 & $1,071,573$ \\
\hline $\begin{array}{l}\text { trans-o-Hydroxy cinnamic } \\
\text { acid }\end{array}$ & 254 & 31.42 & 0.52 & 85.36 & 186,843 \\
\hline \multicolumn{6}{|l|}{ Flavonoids } \\
\hline Rutin & 254 & 27.15 & 0.24 & 146.52 & 339,592 \\
\hline Myricetin & 370 & 33.46 & - & - & 0 \\
\hline Quercetin & 370 & 34.57 & 0.16 & 48.36 & 119,801 \\
\hline
\end{tabular}

Table 3 Total phenolic content (TPC), total flavonoid content (TFC), DPPH radical scavenging activity (RSA), and ferrous ion chelating ability (FIC) of Linum usitatissimum extract

\begin{tabular}{lllll}
\hline & $\begin{array}{l}\text { TPC } \mathbf{m g} \\
\text { GAE/g } \\
\text { extract }\end{array}$ & $\begin{array}{l}\text { TFC } \\
\text { (mgRuE/g } \\
\text { extract) }\end{array}$ & RSA IC $_{\mathbf{5 0}}(\boldsymbol{\mu g} / \mathbf{m L})$ & FIC IC $_{\mathbf{5 0}}(\boldsymbol{\mu g} / \mathbf{m L})$ \\
\hline LUE & 383.4 & 47.1 & $19.3 \pm 1.1$ & $121.1 \pm 1.3$ \\
BHT & - & - & $17.4 \pm 0.5$ & - \\
TOC - & - & $35.6 \pm 0.6$ & - \\
EDTA - & - & - & $68.2 \pm 1.2$ \\
AsCA - & - & - & $1480.0 \pm 3.2$ \\
\hline
\end{tabular}

Values are presented as means $\pm S D(n=3)$

$121.01 \pm 1.3 \mu \mathrm{g} / \mathrm{mL}$ was more active than ascorbic acid, while the ability of EGE to chelate ferrous ions was weaker than that of the positive control (EDTA).

\section{The effect of Linum usitatissimum seeds extracts on cell proliferation}

Figure 2 shows the morphology of LNCaP cells. Figure 1a shows the morphology of the living prostate cancer cells of LNCaP before treatment with LUE. Figure $1 \mathrm{~b}$ exhibited the cells after treatment with the extract after $48 \mathrm{~h}$, as it can be seen, the morphology of the cells has changed and the extract inhibited the growth of the cells.

According to the result of the cytotoxic assay Fig. 3, LUE exhibited a concentration and time depending cytotoxic activity on LNCaP cells line at 24,48 , and $72 \mathrm{~h}$. The extract showed a sufficient cytotoxic effect on LNCaP cells. The values of $8.3,6.3$, and $5.4 \mu \mathrm{g} / \mathrm{mL}$ were calculated for the extract $\mathrm{IC}_{50}$ for 24,48 , and
$72 \mathrm{~h}$ treatment respectively. Besides, Fig. 4 indicates the excellent proliferation inhibition of LUE extract in the high doses compared with Docetaxel as a positive control.

\section{Detection of apoptosis by flow cytometry}

Apoptosis or cell death is considered as an ordered cellular process. The physiological (such as programmed cell destruction, physiologic involution, and regular destruction of cells) and pathological (such as anticancer drug, progressive cell death, and pathologic atrophy of organs and tissues) conditions affect the apoptosis (Wong 2011). Since, resisting death and avoiding apoptosis is one of the ten cancer hallmarks (Hanahan and Weinberg 2011), a study on the apoptosis process is applying for an important role in oncology research (Jian et al. 2018). Figures 5 and 6 exhibit Flow cytometric evaluation and the apoptosis percentage by LUE that was quantitatively determined using PI staining. For this assay, LNCaP cells were treated by $L$. usitatissimum extract with three different concentrations (treatment 1: less than $\mathrm{IC}_{50}$, treatment $2: \mathrm{IC}_{50}$, and treatment 3 more than $\mathrm{IC}_{50}$ ) that were obtained from MTT assay for $24,48,72 \mathrm{~h}$. The treatment of LNCaP cells with LUE significantly increased the percentage of apoptosis as compared to the control. The highest apoptosis was observed for LUE with the concentration of $6.0 \mu \mathrm{g} /$ $\mathrm{mL}$ after $72 \mathrm{~h}$ with the amount of $29.8 \%$, and the smallest one belongs to the concentration of $6.0 \mu \mathrm{g} / \mathrm{mL}$ after $24 \mathrm{~h}$. Figure 7 indicates the concentration of Tumor Necrosis Factor-Alpha (TNF- $\alpha$ ) in several examined groups. The best results were seen in the highest dose of extract and Docetaxel. 


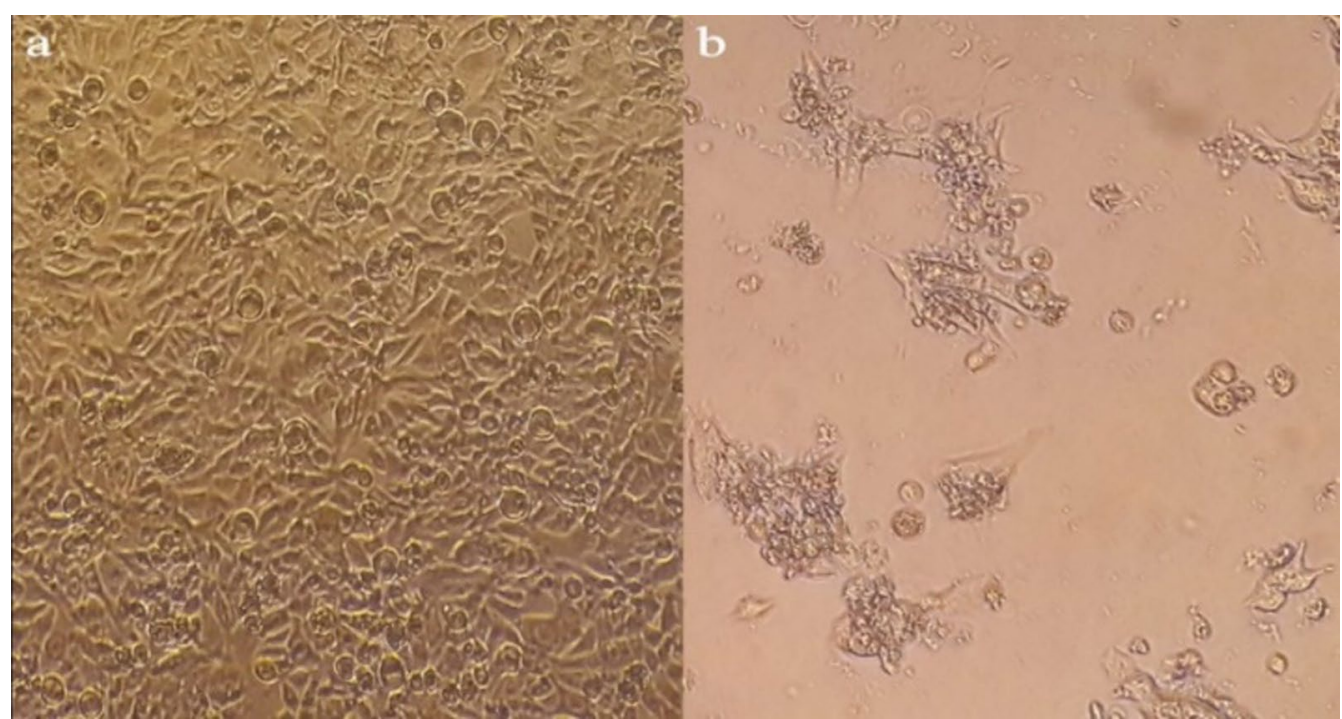

Fig. 2 The morphology of human prostate cancer (LNCap cells) a before treatment with hydroalcoholic extract of $L$. usitatissimum, $\mathbf{b}$ after treatment with hydroalcoholic extract of L. usitatissimum (after $48 \mathrm{~h}$ )

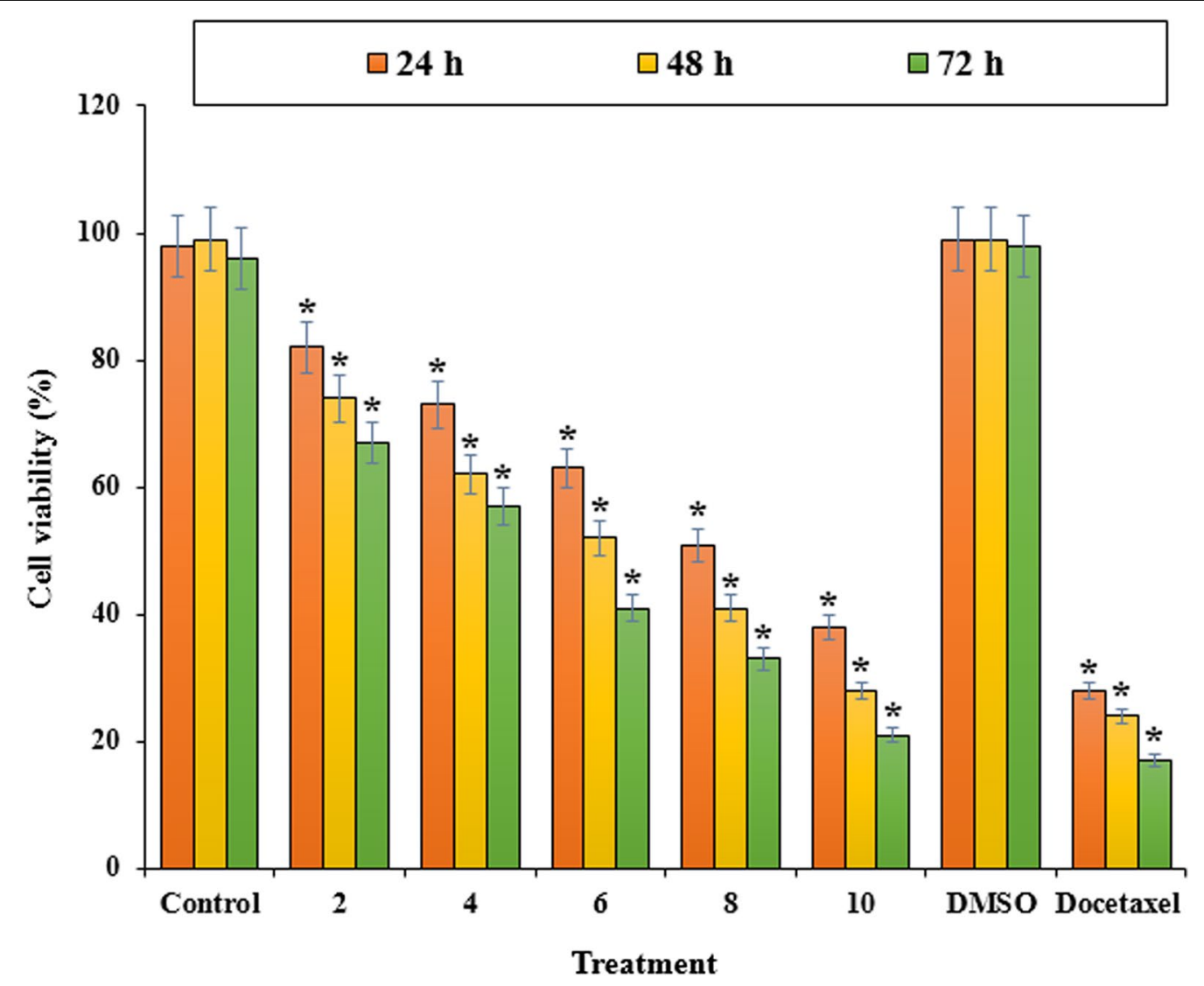

Fig. 3 The effect of L. usitatissimum extract on the viability of LNCaP cells. The viability percentage was measured by MTT assay. LNCaP cells were treated with different concentrations of the extract for 24,48 , and $72 \mathrm{~h}$. ${ }^{*}$ Indicate the significant difference $(p<0.01)$ between experimental groups with control/DMSO groups 


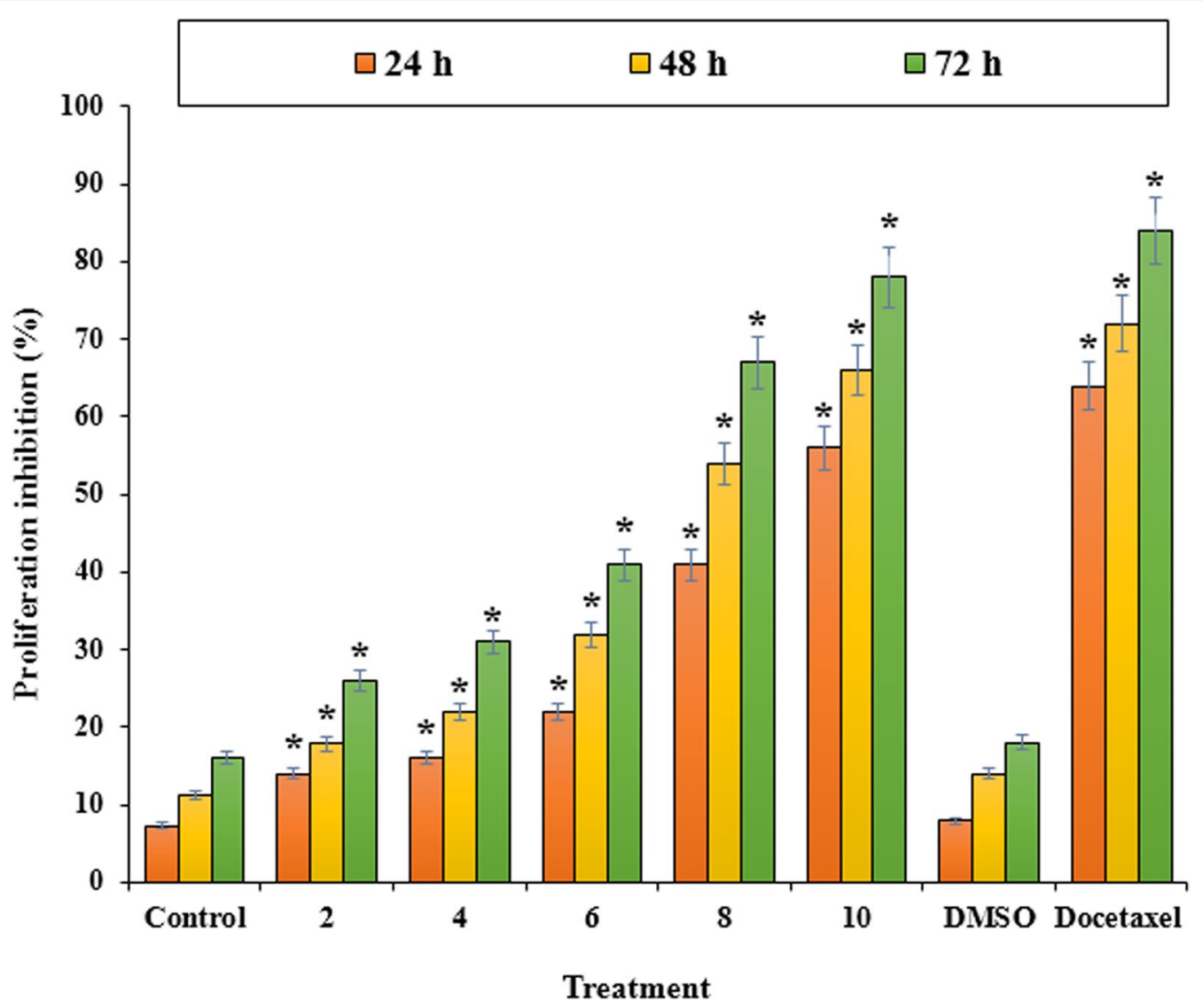

Fig. 4 The effect of L. usitatissimum extract on the proliferation inhibition of LNCaP cells. The percentage was measured by MTT assay. LNCaP cells were treated with different concentrations of the extract for 24,48 , and $72 \mathrm{~h}$. ${ }^{*}$ ndicate the significant difference $(p<0.01)$ between experimental groups with control/DMSO groups

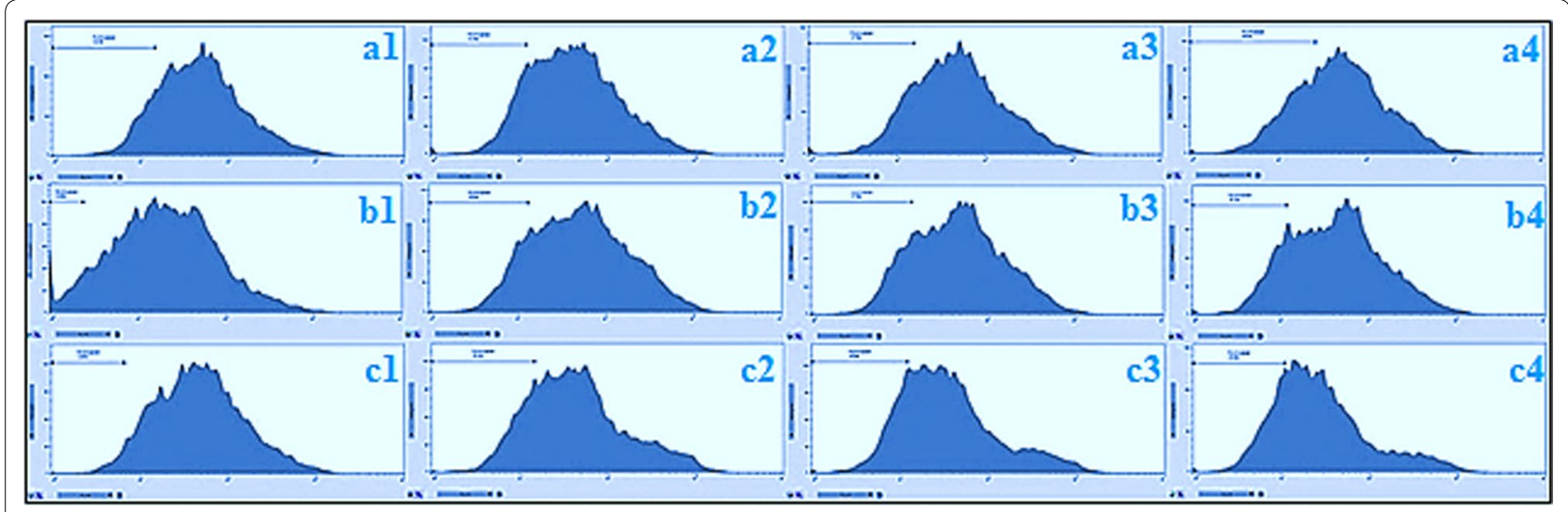

Fig. 5 Flow cytometric evaluation of induced apoptosis using Propidium iodide staining by L. usitatissimum extract extract in LNCaP cells at different times and concentration.a1-4 after $24 \mathrm{~h}$ a1: control a2-4 concentrations of 6.0, 8.3, $10.0 \mathrm{\mu g} / \mathrm{mL}$; b1-4 after $48 \mathrm{~h}$ b1: control, b2-4concentratoions of $4,6.3,8.0 \mu \mathrm{g} / \mathrm{mL} ; \mathrm{cl}-4$ after $72 \mathrm{~h} \mathrm{c1:} \mathrm{control,} \mathrm{c2-4:} \mathrm{concentrations} \mathrm{of} \mathrm{4,} \mathrm{5.4,} 6 \mu \mathrm{g} / \mathrm{mL}$

\section{Bax and caspase 3 gene expressions}

The caspases are a family of protease enzymes. They have a critical role in the cell's apoptotic process $\mathrm{CHu}$ et al. 2019). Caspases are usually activated in the early stages of apoptosis (Kilinc et al. 2020). These proteins affect significantly through activation of the death 


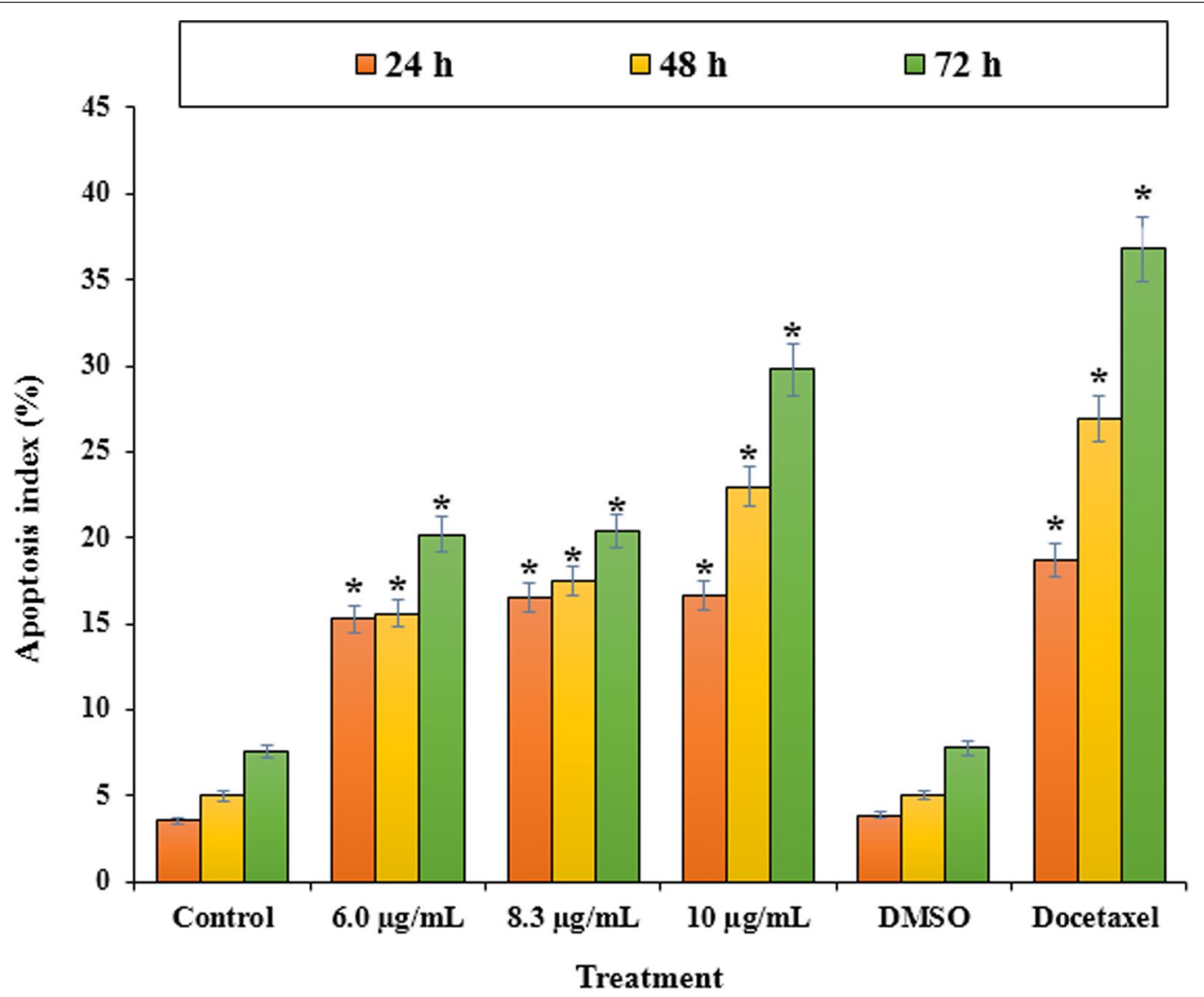

Fig. 6 Pl-staining induced apoptosis on LNCaP cells. LNCaP cells were treated with different concentrations of L. usitatissimum extract for 24,48 , and $72 \mathrm{~h}$. *Indicate the significant difference $(p<0.01)$ between experimental groups with control/DMSO groups

receptors and mitochondrial pathways. Caspase-3 is known as the primary executioner of the family that plays a vital function in reaching apoptotic cell death by cleaving the cellular substrates(Abou-Hashem et al. 2019). Bax (Bcl-2-associated $X$ protein) is a tumor suppressor gene that can promote cell apoptosis (Ammoury et al. 2019; Liu et al. 2015). The expression level of Bax and caspase- 3 is a known way to evaluated induced apoptosis mechanism (Deng et al. 2017).

Figure 8. presents Bax and caspase- 3 gene expression of treated LNCaP cells by $L$. usitatissimum extract using the real-time $\mathrm{qPCR}$ assay. Based on the findings, the gene expression levels were correlated to the selected apoptosis-inducing factor (Bax and caspase-3) after 24, 48, and $72 \mathrm{~h}$. According to the results, the genes had been up-regulated in the extracts-treated cells compared to those of control cells $(" p<0.05$, ${ }^{* * *} p<0.01$ and $\left.* * * 0.001\right)$. The outputs revealed higher levels of expressions for Bax and caspase- 3 in the extract -receiving treatments.

\section{Discussion}

The previous studies on the HPLC analysis revealed the phenolic profile of L. usitatissimum extract. Han et al. (2018). Have reported the plant was rich in $p$-hydroxybenzoic acid $p$-coumaric acid. In another study, HPLC analysis showed sinapic and $p$-hydroxybenzoic acids were abundant compounds in Linum usitatissimum root extract (Gabr et al. 2018). Our result also exhibits the presence of sinapic and $p$-coumaric acid in LUE; however, the extract was rich in gallic acid ferulic, and vanillic acid.

Han et al. (2018) reported the ability of the ethanolic and aqueous extract of flaxseed shell to scavenge DPPH radical with 49.50 and $53.30 \mu \mathrm{g} / \mathrm{mL}$ that was less than LUE activity. On the other hand, the ability of their extract to chelate ferrous ions 9.24 and $8.88 \mu \mathrm{g} / \mathrm{mL}$ was more than the extract of this research.

The chemical constituents of L. usitatissimum extract contributed to the anticancer activity or induced apoptosis on LNCap cells. On the other hand, the synergic 


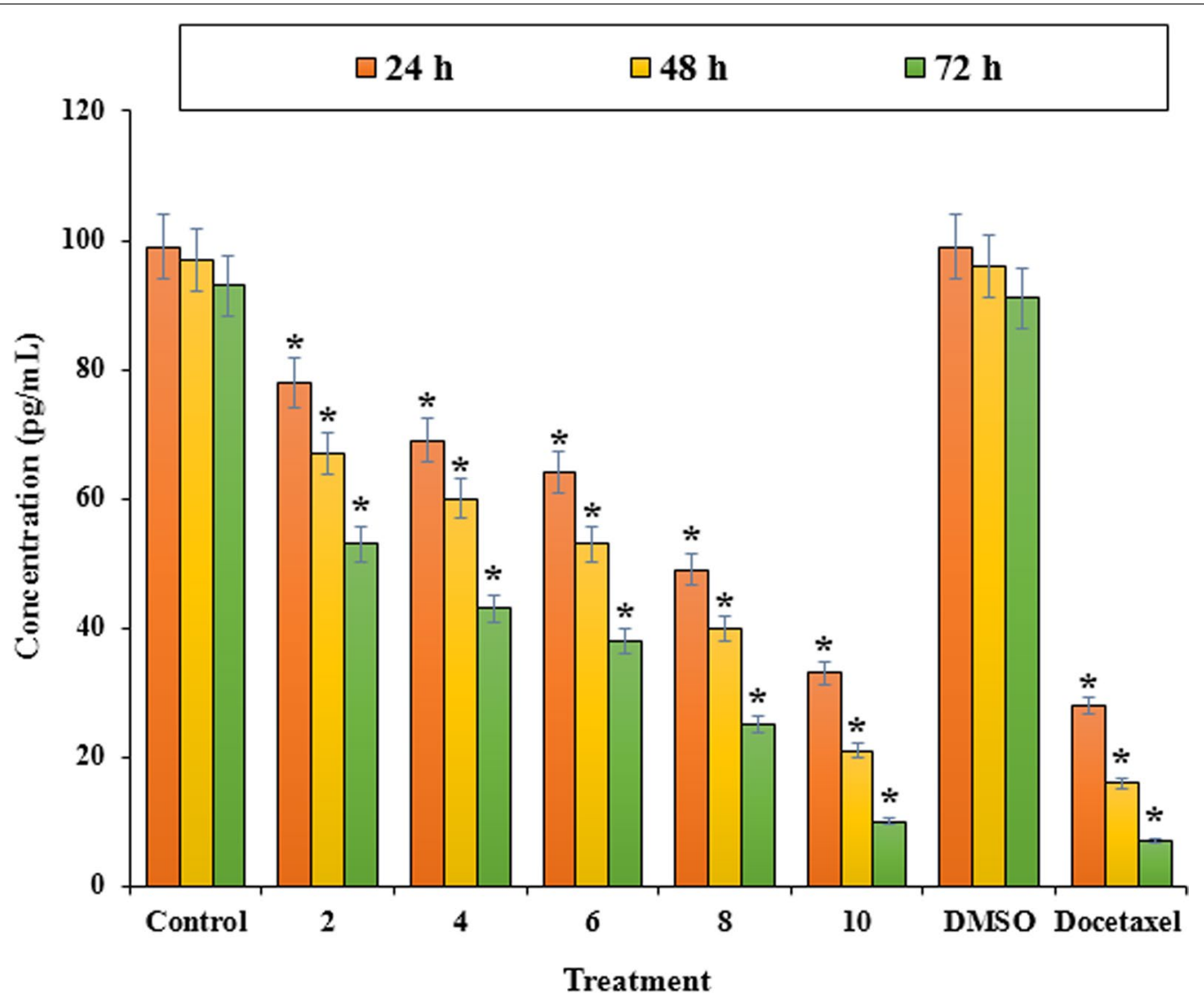

Fig. 7 The effect of L. usitatissimum extract on the concentration of Tumor Necrosis Factor-Alpha (TNF-a) of LNCaP cells. The concentration was measured by the MTT assay. LNCaP cells were treated with different concentrations of the extract for 24,48 , and $72 \mathrm{~h}$. *Indicate the significant difference $(p<0.01)$ between experimental groups with control/DMSO groups

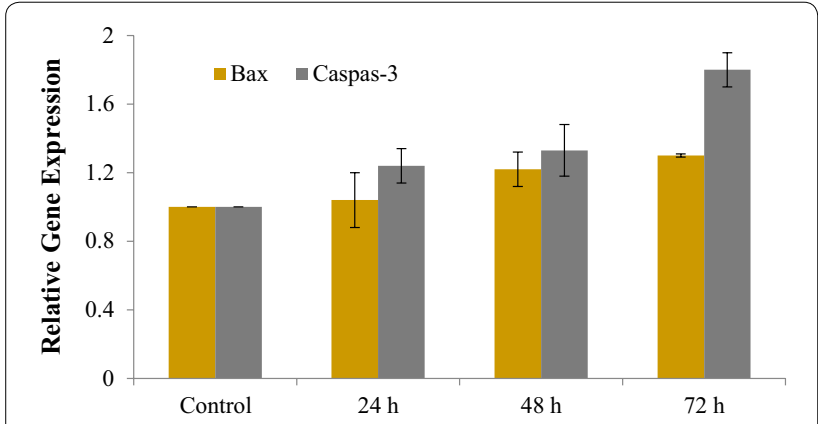

Fig. 8 The effect of L. usitatissimum on the expression of caspase-3 and Bax ratio in LNCaP cells evaluated using the Real-Time PCR method. Cells were treated with the $I_{50}$ dose with the extract. The significant difference between control groups with Treatment group is indicated; ${ }^{*} p<0.05,{ }^{* *} p<0.01$ and ${ }^{* * *} p<0.001 . \mathrm{IC}_{50}$ doses at different times: $24 \mathrm{h:} 8.3 \mu \mathrm{g} / \mathrm{mL} ; 48 \mathrm{h:} 6.3 \mu \mathrm{g} / \mathrm{mL}$ and $72 \mathrm{h:} 5.4 \mu \mathrm{g} / \mathrm{mL}$

effect of the plants' compositions is a well-known factor behind the plants' role to cure a wide range of unhealthy problems (Mahdavi et al. 2017). According to the HPLC results and previous studies, mentioned in the introduction section, L. usitatissimum is rich in phenolic, flavonoids, and lignan compounds. The anticancer activity of these compounds was reported previously. For instance, gallic acid can be considered as an agent in the treatment of prostate cancer (Heidarian et al. 2016). Various reports have been found in the literature on the mechanisms of gallic acid effects on prostate cancer cells. For example, through a ROS-dependent apoptotic mechanism (Russell et al. 2012); through induction of mitochondrial apoptotic signaling pathways (Chen et al. 2009); DNA damage (Liu et al. 2013); reducing protein IL-6 and pAKT signaling protein pathways (Heidarian et al. 2017); increased p27 levels (Reddivari et al. 2010); promotes the levels of phosphatidylinositol 3-kinase (PI3K) and AKT in PC-3 cells (Liu et al. 2011). Ferulic acid is another abundant phenolic compound in the plant extract reported as an active agent against the proliferation of prostate cancer cells (Eitsuka et al. 2014; Eroğlu et al. 2015). Two research groups have reported that chlorogenic acid showed a restraining effect on benign prostatic hyperplasia (Huang 
et al. 2017; Yamagata et al. 2018). Hydroxycinnamic acids such as caffeic acid have a potential inhibitory effect on prostate cancer cell invasion and metastasis (Rocha et al. 2012). Overall, diets that are rich in natural phenolic compounds have valuable effects in reducing prostate cancer incidence (Russo et al. 2017). On the other hand, the synergistic action of phenolic compounds with chemotropic drugs has also been reported as an effective strategy in cancer treatment (Damasceno et al. 2017; Eroglu et al. 2018).

Polyphenols such as Lignans exhibit anticancer activity mainly against breast, prostate, and colon cancer (Zahir et al. 2019). Lignans prevent prostate cancer growth via numerous mechanisms of action (Yatkin et al. 2014). These molecules were the most effective as a death receptor-sensitizing agent (Peuhu et al. 2010).

Based on this research, gallic, ferulic, and vanillic acid were found as the abundant phenolic compounds in the hydroalcoholic extract of L. usitatissimum seeds (flaxseeds). The plant extract showed a high level of antioxidant activity to scavenge the free radical of DPPH with a low $\mathrm{IC}_{50}$, even less than BHT. L. usitatissimum extract exhibited a remarkable cytotoxicity effect on human prostate cancer cells of LNCaP. The values of 8.3, 6.3, and $5.4 \mu \mathrm{g} / \mathrm{mL}$ were obtained as $\mathrm{IC}_{50}$ for the treatment of the cell lines after 24,48 , and $72 \mathrm{~h}$. The extract also induced apoptosis on the cells line with a minimum of $15.3 \%$ and a maximum of $29.8 \%$. The gene expression of caspase- 3 and Bax also increased after treatment of the cells with the plant extract. Based on our in vitro study with LNCaP cells, L. usitatissimum induces apoptotic cell death. As follow up to this, further studies are needed to evaluate the therapeutic potential of L. usitatissimum against $\mathrm{PCa}$ in experimental in vivo models.

\section{Authors' contributions \\ All authors contributed and discussed in the analysis and results and commented on the manuscript. All authors read and approved the final manuscript.}

\section{Funding}

No funding was received.

\section{Ethics approval and consent to participate}

consentThis article does not contain any studies with human participants or animals performed by any of the authors.

\section{Consent for publication}

For this type of study, formal consent is not required.

\section{Competing interests}

The authors declare that they have no competing interest.

\section{Author details}

${ }^{1}$ Department of Urology, Beijing Tiantan Hospital,Capital Medical University, Beijing 100070, China. ${ }^{2}$ Department of Pharmacy, The Fourth Affiliated Hospital of Nanjing Medical University, Nanjing 210031, Jiangsu, China.

${ }^{3}$ Department of Urology, Occupational Disease Hospital of Xinjiang Uygur
Autonomous Region, Urumqi 830000, Xinjiang, China. ${ }^{4}$ Jiangxi Research Institute of Traditional Chinese Medicine, Nanchang 330046, Jiangxi, China. ${ }^{5}$ Department of Chemistry, Faculty of Science, Hakim Sabzevari University, 96179-76487 Sabzevar, Iran. ${ }^{6}$ Cellular and Molecular Research Center, Department of Anatomy, Sabzevar University of Medical Sciences, Sabzevar, Iran. ${ }^{7}$ Cellular and Molecular Research Center, Sabzevar University of Medical Sciences, Sabzevar, Iran.

Received: 30 April 2020 Accepted: 27 October 2020

Published online: 10 November 2020

\section{References}

Abou-Hashem MMM, Abo-elmatty DM, Mesbah NM, EL-Mawgoud AMA (2019) Induction of sub-G0 arrest and apoptosis by seed extract of Moringa peregrina (Forssk.) Fiori in cervical and prostate cancer cell lines. J Integr Med 17(6):410-422

Ammoury C, Younes M, El Khoury M, Hodroj MH, Haykal T, Nasr P, Sily M, Taleb RI, Sarkis R, Khalife R (2019) The pro-apoptotic effect of a Terpene-rich Annona cherimola leaf extract on leukemic cell lines. BMC Complement Altern Med 19(1):1-10

Azadbakht M, Hosseini AS, Davoodi A (2019) Materia medica in Persian medicine. Arjmand Pub, Tehran

Calado A, Neves PM, Santos T, Ravasco P (2018) The effect of flaxseed in breast cancer: a literature review. Front Nutr 5:4

Chen H-M, Wu Y-C, Chia Y-C, Chang F-R, Hsu H-K, Hsieh Y-C, Chen C-C, Yuan S-S (2009) Gallic acid, a major component of Toona sinensis leaf extracts, contains a ROS-mediated anti-cancer activity in human prostate cancer cells. Cancer Lett 286(2):161-171

Chen X, Liu J, Cheng L, Li C, Zhang Z, Bai Y, Wang R, Han T, Huang C, Kong Y (2019) Inhibition of noncanonical Wnt pathway overcomes enzalutamide resistance in castration-resistant prostate cancer. Prostate 80(3):256-266

Damasceno SS, Dantas BB, Ribeiro-Filho J, Araújo AM, da Costa GM (2017) Chemical properties of caffeic and ferulic acids in biological system: implications in cancer therapy. A review. Curr Pharm Des 23(20):3015-3023

Dasari S, Samy ALPA, Kajdacsy-Balla A, Bosland MC, Munirathinam G (2018a) Vitamin $\mathrm{K} 2$, a menaquinone present in dairy products targets castrationresistant prostate cancer cell-line by activating apoptosis signaling. Food Chem Toxicol 115:218-227

Dasari S, Samy ALPA, Narvekar P, Dontaraju VS, Dasari R, Kornienko A, Munirathinam G (2018b) Polygodial analog induces apoptosis in LNCaP prostate cancer cells. Eur J Pharmacol 828:154-162

DeLuca JA, Garcia-Villatoro EL, Allred CD (2018) Flaxseed bioactive compounds and colorectal cancer prevention. Current oncology reports 20(8):59

Deng Y, Li Y, Yang F, Zeng A, Yang S, Luo Y, Zhang Y, Xie Y, Ye T, Xia Y (2017) The extract from Punica granatum (pomegranate) peel induces apoptosis and impairs metastasis in prostate cancer cells. Biomed Pharmacother 93:976-984

Duygu A, Yilmaz G (2018) Some medicinal plants used as folk medicine for colon cancer. CUPMAP 1(1):42-47

Eitsuka T, Tatewaki N, Nishida H, Kurata T, Nakagawa K, Miyazawa T (2014) Synergistic inhibition of cancer cell proliferation with a combination of $\delta$-tocotrienol and ferulic acid. Biochem Biophys Res Commun 453(3):606-611

Eroglu C, Avci E, Secme M, Dodurga Y, Vural H, Kurar E (2018) The combination effect of ferulic acid and gemcitabine on expression of genes related apoptosis and metastasis in PC-3 prostate cancer cells. Eur J Biol $77(1): 32-37$

Eroğlu C, Seçme M, Bağcı G, Dodurga Y (2015) Assessment of the anticancer mechanism of ferulic acid via cell cycle and apoptotic pathways in human prostate cancer cell lines. Tumor Biol 36(12):9437-9446

Fadzir UA, Darnis DS, Mustafa BE, Mokhtar KI (2018) Linum usitatissimum as an antimicrobial agent and a potential natural healer: a review. AOS 13(2):55-62

Gabr AM, Mabrok HB, Abdel-Rahim EA, El-Bahr MK, Smetanska I (2018) Determination of lignans, phenolic acids and antioxidant capacity in transformed hairy root culture of Linum usitatissimum. Nat Prod Res 32(15):1867-1871 
Garros L, Drouet S, Corbin C, Decourtil C, Fidel T, Lebas de Lacour J, Leclerc EA, Renouard S, Tungmunnithum D, Doussot J (2018) Insight into the influence of cultivar type, cultivation year, and site on the lignans and related phenolic profiles, and the health-promoting antioxidant potential of flax (Linum usitatissimum L) seeds. Molecules 23(10):2636

Han H, YIlmaz H, Gülçin I (2018) Antioxidant activity of flaxseed (Linum usitatissimum L.) shell and analysis of its polyphenol contents by LC-MS/MS. Rec Nat Prod 12(4):397-402

Hanahan D, Weinberg RA (2011) Hallmarks of cancer: the next generation. Cell 144(5):646-674

Heidarian E, Keloushadi M, Ghatreh-Samani K, Jafari-Dehkordi E (2017) Gallic acid inhibits invasion and reduces IL-6 gene expression, PSTAT3, PERK1/2, and PAKT cellular signaling proteins in human prostate cancer DU-145 cells. Int J Cancer Manag 10(11):e9163

Heidarian E, Keloushadi M, Ghatreh-Samani K, Valipour P (2016) The reduction of IL-6 gene expression, pAKT, pERK1/2, pSTAT3 signaling pathways and invasion activity by gallic acid in prostate cancer PC3 cells. Biomed Pharmacother 84:264-269

Herchi W, Ammar KB, Bouali I, Abdallah IB, Guetet A, Boukhchina S (2016) Heating effects on physicochemical characteristics and antioxidant activity of flaxseed hull oil (Linum usitatissimum L.). Food Sci Technol 36(1):97-102

Hosseinpoor Mohsen Abadi Z, Mahdavi B, Rezaei-Seresht E (2016) Contents of aerial parts of Salvia leriifolia Benth. J Chem Health Risks 6(3):185-194

Hu T, Linghu K, Huang S, Battino M, Georgiev MI, Zengin G, Li D, Deng Y, Wang Y, Cao H (2019) Flaxseed extract induces apoptosis in human breast cancer MCF-7 cells. Food Chem Toxicol 127:188-196

Huang Y, Chen H, Zhou X, Wu X, Hu E, Jiang Z (2017) Inhibition effects of chlorogenic acid on benign prostatic hyperplasia in mice. Eur J Pharmacol 809:191-195

Jian B, Zhang H, Han C, Liu J (2018) Anti-cancer activities of diterpenoids derived from Euphorbia fischeriana Steud. Molecules 23(2):387-398

Kilinc K, Demir S, Turan I, Mentese A, Orem A, Sonmez M, Aliyazicioglu Y (2020) Rosa canina extract has antiproliferative and proapoptotic effects on human lung and prostate cancer cells. Nutr Cancer 72(2):273-282

Lazić BD, Pejić BM, Kramar AD, Vukčević MM, Mihajlovski KR, Rusmirović JD, Kostić MM (2018) Influence of hemicelluloses and lignin content on structure and sorption properties of flax fibers (Linum usitatissimum L.). Cellulose 25(1):697-709

Liu K-C, Huang A-C, Wu P-P, Lin H-Y, Chueh F-S, Yang J-S, Lu C-C, Chiang J-H, Meng M, Chung J-G (2011) Gallic acid suppresses the migration and invasion of PC-3 human prostate cancer cells via inhibition of matrix metalloproteinase-2 and-9 signaling pathways. Oncol Rep 26(1):177-184

Liu KC, Ho HC, Huang AC, Ji BC, Lin HY, Chueh FS, Yang JS, Lu CC, Chiang JH, Meng M (2013) Gallic acid provokes DNA damage and suppresses DNA repair gene expression in human prostate cancer PC-3 cells. Environ Toxicol 28(10):579-587

Liu X, He Y, Li F, Huang Q, Kato TA, Hall RP, Li C-Y (2015) Caspase-3 promotes genetic instability and carcinogenesis. Mol Cell 58(2):284-296

Mahdavi B, Yaacob W, Din LB, Jahangirian H (2013) Antioxidant activity of consecutive extracts of the base, stem and leaves of Etlingera brevilabrum. Asian J Chemistr 25(7):3937-3941

Mahdavi B, Yaacob WA, Din LB (2017) Chemical composition, antioxidant, and antibacterial activity of essential oils from Etlingera sayapensis AD Poulsen \& Ibrahim. Asian Pac J Trop Med 10(8):819-826

Mirza MB, Elkady Al, Al-Attar AM, Syed FQ, Mohammed FA, Hakeem KR (2018) Induction of apoptosis and cell cycle arrest by ethyl acetate fraction of Phoenix dactylifera L. (Ajwa dates) in prostate cancer cells. J Ethnopharmacol 218:35-44

$\mathrm{Ni}$ J, Mahdavi B, Ghezi S (2019) Chemical composition, antimicrobial, hemoIytic, and antiproliferative activity of essential oils from Ephedra intermedia Schrenk \& Mey. J Essent Oil-Bear Plants 22(6):1562-1570

Nwachukwu ID, Aluko RE (2018) Physicochemical and emulsification properties of flaxseed (Linum usitatissimum) albumin and globulin fractions. Food Chem 255:216-225
Pallag A, Jurca T, Pasca B, Sirbu V, Honiges A, Costuleanu M (2016) Analysis of phenolic compounds composition by HPLC and assessment of antioxidant capacity in Equisetum arvense L. extracts. Rev Chim 67:1623-1627

Peuhu E, Rivero-Müller A, Stykki H, Torvaldson E, Holmbom T, Eklund P, Unkila M, Sjöholm R, Eriksson J (2010) Inhibition of Akt signaling by the lignan matairesinol sensitizes prostate cancer cells to TRAlL-induced apoptosis. Oncogene 29(6):898-908

Reddivari L, Vanamala J, Safe SH, Miller JC Jr (2010) The bioactive compounds a-chaconine and gallic acid in potato extracts decrease survival and induce apoptosis in LNCaP and PC3 prostate cancer cells. Nutr Cancer 62(5):601-610

Rocha LD, Monteiro MC, Teodoro AJ (2012) Anticancer properties of hydroxycinnamic acids-a Review. Cancer Clin Oncol 1(2):109-121

Russell LH, Mazzio E, Badisa RB, Zhu Z-P, Agharahimi M, Oriaku ET, Goodman CB (2012) Autoxidation of gallic acid induces ROS-dependent death in human prostate cancer LNCaP cells. Anticancer Res 32(5):1595-1602

Russo Gl, Campisi D, Di Mauro M, Regis F, Reale G, Marranzano M, Ragusa R, Solinas T, Madonia M, Cimino S (2017) Dietary consumption of phenolic acids and prostate cancer: a case-control study in sicily, Southern Italy. Molecules 22(12):2159

Safarpoor M, Ghaedi M, Yousefinejad M, Javadian H, Asfaram A, Ghasemi Z, Jaberi H, Rahimi D (2018) Podophyllotoxin extraction from Linum usitatissimum plant and its anticancer activity against HT-29, A-549 and MDAMB-231 cell lines with and without the presence of gold nanoparticles. Appl Organomet Chem 32(2):e4024

Sharma J, Singh R, Goyal P (2014) Chemopreventive role of flaxseed oil against chemical induced skin cancer in mammals. J Cancer Biol Treat 1:001

Urhan BK, Demir Ü, Özer TÖ, Doğan HÖ (2020) Electrochemical fabrication of Ni nanoparticles-decorated electrochemically reduced graphene oxide composite electrode for non-enzymatic glucose detection. Thin Solid Films 693:137695

Wei C-K, Thakur K, Liu D-H, Zhang J-G, Wei Z-J (2018) Enzymatic hydrolysis of flaxseed (Linum usitatissimum L.) protein and sensory characterization of Maillard reaction products. Food Chem 263:186-193

Wong RS (2011) Apoptosis in cancer: from pathogenesis to treatment. J Exp Clin Cancer Res 30(1):87-100

Yamagata K, Izawa Y, Onodera D, Tagami M (2018) Chlorogenic acid regulates apoptosis and stem cell marker-related gene expression in A549 human lung cancer cells. Mol Cell Biochem 441(1-2):9-19

Yatkin E, Polari L, Laajala TD, Smeds A, Eckerman C, Holmbom B, Saarinen NM, Aittokallio T, Mäkelä SI (2014) Novel lignan and stilbenoid mixture shows anticarcinogenic efficacy in preclinical PC-3M-luc2 prostate cancer model. PLOS ONE 9(4):e93764

Yoo S, Gujrathi I, Haider MA, Khalvati F (2019) Prostate cancer detection using deep convolutional neural networks. Sci Rep 9:19518

Yoon KH, Park KJ, Yin J, Yoon KH, Lee JY, Hwang YJ, Lee DI, Choi YW, Lee MW (2016) Antioxidative and antitumor effects of isoflavones isolated from the leaves of Maackia fauriei. Rec Nat Prod 10(4):441-451

Zahir A, Nadeem M, Ahmad W, Giglioli-Guivarc'h N, Hano C, Abbasi BH (2019) Chemogenic silver nanoparticles enhance lignans and neolignans in cell suspension cultures of Linum usitatissimum L. PCTOC 136(3):589-596

Zhu F, Li J (2019a) Physicochemical and sensory properties of fresh noodles fortified with ground linseed (Linum usitatissimum). LWT 101:847-853

Zhu F, Li J (2019b) Physicochemical properties of steamed bread fortified with ground linseed (Linum usitatissimum). Int J Food Sci Technol 54(5):1670-1676

\section{Publisher's Note}

Springer Nature remains neutral with regard to jurisdictional claims in published maps and institutional affiliations. 